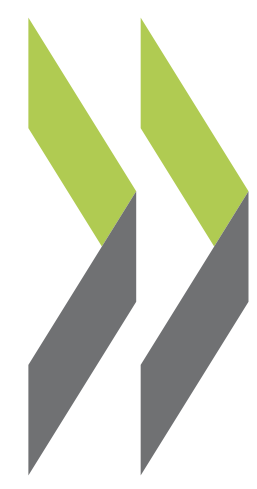

OECD Local Economic and Employment Development (LEED) Papers 2018/03

Integration of Migrants, Refugees and Asylum Seekers in Remote Areas with Declining Populations
Giulia Galera,

Leila Giannetto,

Andrea Membretti,

Antonella Noya 


\section{Integration of Migrants, Refugees and Asylum Seekers in Remote Areas with Declining Populations}

This paper examines whether immigration can operate as a counter-process of depopulation and economic recession. Based on the comparative analysis of four case studies in Belluno (Italy), Klagenfurt-Villach (Austria), Dalarna (Sweden), and Haßberge (Germany), it analyses the key socio-economic factors explaining the successful integration of migrants, refugees, status holders and asylum seekers and examines under which conditions the arrival of newcomers can turn into a local development opportunity for these territories. The case studies feature four remote territories with the following common characteristics: they have undergone significant socio-economic transformations over the past decade, they face a population decline with an alarming outmigration of youth combined with an increasing ageing population, and central governments have channelled recent immigration and asylum seekers to peripheral areas to counterbalance negative demographic trends. Results show that integration paths undertaken by recipients differ significantly across the four territories. However, all case studies suggest that stable jobs and accommodations render remote and mountain localities attractive for refugees and status holders, who are usually more inclined to move to urban centres. Lastly, results from the case studies highlight the importance of designing individualised integration paths backed by social inclusion initiatives that can incite spontaneous collaborations and work relations with local inhabitants.

\section{Authors}

Giulia Galera, Senior Researcher, EURICSE

Leila Giannetto, Researcher, EURICSE

Andrea Membretti, Senior Researcher, EURAC

Antonella Noya, Head of Unit, OECD

JEL: H75, J08, J61, J68, 131, 035

Keywords: immigration, refugees, asylum-seekers, migrants, ageing, integration, social innovation

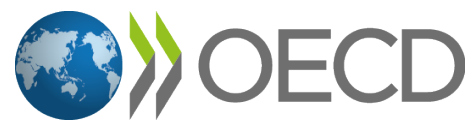


OECD Working Papers should not be reported as representing the official views of the OECD or of its member countries. The opinions expressed and arguments employed are those of the author(s).

This document, as well as any [statistical] data and map included herein, are without prejudice to the status of or sovereignty over any territory, to the delimitation of international frontiers and boundaries and to the name of any territory, city or area.

Working Papers describe preliminary results or research in progress by the author(s) and are published to stimulate discussion on a broad range of issues on which the OECD works. Comments on Working Papers are welcome, and may be sent to the Centre for Entrepreneurship, SMEs, Regions and Cities, OECD, 2 rue André-Pascal, 75775 Paris Cedex 16, France.

Authorised for publication by Lamia Kamal-Chaoui, Director, Centre for Entrepreneurship, SMEs, Regions and Cities, OECD.

OECD Local Economic and Employment Development (LEED) Working Papers are published on: https://doi.org/10.1787/20794797.

\section{(C) OECD 2018}

You can copy, download or print OECD content for your own use, and you can include excerpts from OECD publications, databases and multimedia products in your own documents, presentations, blogs, websites and teaching materials, provided that suitable acknowledgment of OECD as source and copyright owner is given. All requests for commercial use and translation rights should be submitted to rights@oecd.org. 


\section{Introduction}

This report analyses the practices of integration of migrants, including refugees, asylum seekers and status holders, in remote areas $^{1}$ with declining populations ${ }^{2}$.

In line with EU and previous OECD documents and guidelines, the initial stance of this report is that migration has a potential to trigger development ${ }^{3}$, in the medium and long run (OECD, 2018a) especially in remote areas with a depopulation trend. For this to happen, adequate reception and integration policies, tailored to remote areas, are needed. This presupposes that: 1) remote areas should not be simply regarded as relief valves for asylum seekers unwelcome in urban areas, and that 2) attention is paid specifically to the management of reception and to the design of proper integration pathways. In fragile areas, the impact of mis- or poor management is notably more severe both for the asylum seekers, who normally lack support structures, and for the hosting communities, which tend to be more homogeneous and hence less migration-friendly ${ }^{4}$. At the same time, however, a welldesigned reception and integration project can have more visible beneficial impacts in remote areas when compared to urban contexts: it is more likely to create win-win situations, including the revitalisation of abandoned spaces and the generation of a new demand for general-interest services otherwise at risk of survival.

These opposed dynamics clearly emerge from the case studies used for the analysis in this paper, which focuses on remote areas located in four different European regions (TL3): Belluno (Italy), Klagenfurt-Villach (Austria), Dalarna (Sweden), and Haßberge (Germany) ${ }^{5}$. Integration paths undertaken by recipients differ significantly across the four territories, ranging from good practices of integration of recipients in the labour market to

${ }^{1}$ The OECD definition of remote areas is based on two main indicators: settlement density and accessibility of urban centres. The analysis undertook here builds on the "OECD typology" to explain "regional differences in economic and labour market performance". This typology classifies "rural and intermediate regions as remote when $50 \%$ of the regional population needs at least 60 (45) minutes of driving time to reach a populated centre with at least 50,000 inhabitants. If this condition does not hold, then rural and intermediate regions are classified as close to a populated centre." (Brezzi et al., 2011, p. 5).

${ }^{2}$ Population decline in the selected territories is due to either low birth rates or negative net migration or both.

${ }^{3}$ The refugee working-age population of European countries provided an "additional increase of $0.26 \%$ of the working-age population of European countries between January 2014 and December 2017 (Figure 3.8). By December 2020, this net effect could amount to $0.29-0.36 \%$. The overall net effect is therefore small. Indeed, United Nations population projections indicate that, over the same period 2014-20, the working-age population of European countries is set to decrease by $2 \%$." (OECD, 2018b: 148).

${ }^{4}$ As highlighted by the OECD (2018) a), there is a positive correlation between diversity in population and perception of migration (at the regional level).

5 The classification of TL3 regions made by OECD identifies five typologies (in the extended version) based on the population share in rural areas and the closeness of rural areas to urban centres: Predominantly urban (PU), Intermediate close to a city (INC), Intermediate Remote (INR), Predominantly Rural close to a city (PRC), Predominantly Rural Remote (PRR). The four territories identified for the present study are placed in remote areas of their TL3 regions. The corresponding TL3 have been classified in the 2018 typology as follows: Belluno - PRR; Klagenfurt-Villach INC; Dalarna - PRR; Haßberge - PRC. 
less successful ones. In these latter cases, asylum seekers tend to move elsewhere as soon as they are granted the protection status.

The case studies were selected among remote territories facing a population decline, which is expected to worsen over the next decades, and with a predominant component of ageing population. Moreover, the selected territories have undergone significant socio-economic transformations over the past decades and are witnessing an alarming outmigration of youth. Another common feature across all four territories is that recent immigration flows connected to the redistribution of asylum seekers to peripheral areas by central governments counterbalance negative demographic trends.

The comparative case study analysis draws on previous socio-demographic research conducted at EU level and examines whether immigration can operate as a counter-process of depopulation and economic recession (OECD, 2018a; Heleniak, 2018; Membretti, 2016; Corrado, Dematteis and Di Gioia, 2014; Machold, Dax and Strahl, 2013; Maurer and Wytrzens, 2012; Bender and Kanitscheider, 2012; Mihailescu, 2011; Iorio and Corsale, 2010; Helberg, 2010).

Based on the comparative analysis of the four case studies in the context of their national reception and integration systems, this report analyses:

- the key socio-economic factors explaining the successful integration of migrants, refugees, status holders and asylum seekers in the selected territories. An indicator of successful integration is the share of recipients overall hosted that decide to settle down in the receiving territory once granted the status of refugee or some other form of international protection. This happens normally when recipients succeed in finding both a regular job and a suitable accommodation. An additional indicator of successful integration is the number of family reunifications accomplished;

- under which conditions the arrival of newcomers can turn into a local development opportunity for sparsely populated and at risk of being abandoned territories. This implies the creation of a set of favourable conditions, including new employment and a new demand for services and goods, resulting from the increase in number of people residing in a given territory. These may entail the survival or re-opening of schools, medical clinics and local shops otherwise doomed to close down.

\section{The reception of asylum seekers, refugees and status holder in remote areas: trends and challenges across Europe}

\subsection{Context and definitions}

The reception of asylum seekers, refugees and status holders is a fast-changing domain. This is due to ever-changing characteristics of both migration flows and relevant public policies, whose impact in remote areas remains largely unexplored. While comparisons of migrants' integration outcomes have been consistently attempted at national and regional levels, growing attention is being paid to the challenges and opportunities posed by migrants' integration in remote areas (OECD/EU, 2015; OECD, 2018a; Heleniak, 2018)

According to the OECD report on local integration of migrants and refugees (2018a), between 2005 and 2015 the share of foreign born population grew by $80 \%$ in all OECD regions, and particularly in regions such as the north of Italy and Germany and the south of Sweden (5 to 12 percentage points increase). In terms of geographic distribution of migrants, those who are not compelled or forced to flee (e.g. EU migrants) are present 
chiefly in urban areas. Conversely, asylum seekers, refugees and status holders, especially of recent arrival, are dispersed more evenly than other migrants across EU regions and they are on average more present in non-urban regions when compared to natives due to national dispersal policies (OECD, 2018a, pp. 48-49).

In EU countries, immigration policies, including dispersal mechanisms, are developed at the EU and national levels ${ }^{6}$, whereas integration and reception policies are mainly implemented at the local level. This implies that the role of local authorities, and the relations they establish with private reception providers, are paramount in designing sustainable integration measures that can contribute to taking stock of the skills integration potential of newcomers and generating a beneficial impact upon the receiving territories alike.

Before delving further into the description of national policies and local practices of reception and integration, it is necessary to clean the slate and adopt a common vocabulary, particularly when it comes to highly politicised words such as "migrants", "refugees", "asylum seekers", and "integration".

\section{Migrants}

The term "migrant" describes the foreign-born population who have ever migrated from their country of birth to their current country of residence (OECD, 2018b; Lemaitre, 2007; Lemaitre and Dumont, 2005)

This report considers migrants as a large group that includes (OECD, 2018a, pp. 26-27):

- EU migrants: those who have emigrated from one EU country to another EU country,

- third-country nationals: those who have migrated from a non-EU country to an EU country,

- persons who have fled their country of origin (including stateless people) and seek or have been granted international protection.

The following terms are used to specify the latter:

- refugees: those who have been recognised the refugee status on the basis of the 1951 Geneva Convection Relating to the Status of Refugees,

- $\quad$ status holders, including holders of subsidiary ${ }^{7}$ or humanitarian protection status: those benefiting from protection statuses recognised by national asylum laws or EU legislation (Directive 2011/95/EU),

- asylum seekers: those who have submitted a claim for international protection but are awaiting the final decision.

This report systematically distinguishes which group, among the abovementioned, is targeted by reception and integration policies at the national, regional, and local levels (OECD, 2016; UNSD, 2017).

${ }^{6}$ In November 2015, the European Commission provided guidance to member states on how to allocate funds to address the crisis, using specific lines of funding, including the European Agricultural Fund for Rural Development and the European Maritime and Fisheries Fund.

${ }^{7}$ https://ec.europa.eu/home-affairs/content/subsidiary-protection_en 


\section{Integration}

Numerous scholars and practitioners have attempted to define comparable indicators for assessing integration (Carrera, 2008; Wihtol de Wenden et al., 2008). Nonetheless, the term "integration" remains difficult to measure and compare universally. This study draws on the European Commission definition of successful integration as a two-way effort, in which the rights of migrants are recognised thanks to the efforts of the hosting community. At the same time, the hosting community is expected to benefit from the presence of migrants, who are asked to embrace the civic values and duties of the hosting community (European Commission, 2003).

\subsection{Dispersal policies targeting asylum seekers and refugees: friends or foes of remote areas with declining population?}

Hosting countries have managed the arrival of high numbers of asylum seekers through the use and sometimes reform of dispersal policies. Three categories of dispersal policies can be distinguished across EU countries:

- policies that apply proportionality criteria for the distribution of asylum seekers within the country based, for example, on GDP, population, presence of previous applicants. This is the case of Austria and Germany;

- policies that distribute asylum seekers within the country according to the availability of places in the reception centres. This is the case of Italy;

- policies that apply more complex dispersal mechanisms which have been introduced to match the characteristics of newcomers (i.e. refugees and status holders) with the labour demand of the hosting territory. So far, only the Netherlands and Sweden have attempted to apply these mechanisms (OECD, 2018a, p. 108).

National governments conceived dispersal policies to avoid concentration of asylum seekers in some territories. However, nowadays national governments sometimes devolve these competences to local municipalities in different degrees: while dispersal policies remain under the aegis of the national governments, municipalities' role is to determine how to distribute asylum seekers, refugees and status holders within their own territory (e.g., Germany and the SPRAR system in Italy) (OECD, 2018a; Piccinni and Proietti, forthcoming). Therefore, remote areas are hosting not only willing migrants but also asylum seekers, refugees and status holders who are subject to national dispersal policies to avoid over-concentration (Nordregio, 2004).

A debated issue concerning the effects of dispersal policies is that the integration of migrants who are subject to compulsory dispersal policies might be more problematic as compared to the integration of people who chose voluntarily to settle in a specific territory $\left(\mathrm{OECD}, 2016_{[17]}\right)$. The literature finds mixed evidence on the impact of dispersal policies. While some scholars note that small villages offer greater opportunities to interact with the hosting community, others highlight the difficulty faced by recipients in remote localities to maintain ties with their ethnic networks (OECD, 2016; Andersson, Brama and Holmqvist, 2010; European Foundation for the Improvement of Living and Working Conditions, 2007). Another important aspect is the higher job opportunities accessible in urban contexts when compared to remote areas (OECD, 2018a). Indeed, according to a research carried out in Sweden in the early 2000s' "refugees that had been dispersed earned $25 \%$ less, were more often unemployed and much more often reliant on welfare benefits", 
as they were dispersed in places where they would not remain after receiving their status (Scholten et al., 2017, p. 33).

The literature has also shown that settling permanently or semi-permanently in a specific location is an effective way whereby asylum seekers, status holders and refugees can interact with the host community.

Nevertheless, what most studies carried out so far underestimate is that the challenges posed by the arrival of asylum seekers can be managed in significantly diverse ways locally, depending on the actors involved and mechanisms eventually implemented to regulate the contracting out of reception and integration services.

\subsection{Methodology for analysing the selected territories}

Following a preliminary analysis of the national demographic dynamics, migration flows, reception conditions and integration measures in Austria, Germany, Italy and Sweden, the next sections draw on specific territories (one per country) that are hosting asylum seekers. These territories include one or more municipalities covered by the selected reception and integration initiative, which is alternatively managed by public authorities and/or by private providers (on behalf of public authorities).

A comparative case study analysis aims to explore in four selected territories the degree of socio-economic integration of recipients, the roles and relations established among the different public and private local actors involved in the welcome and integration process and the extent to which the arrival of newcomers has turned into a development opportunity for the selected territories.

The case study analysis is structured along three sections:

- Analysis of the socio-economic context.

- Description of the operational model of reception implemented.

- Tentative assessment of the impact of the reception initiative in terms of integration of recipients and local development opportunities for the selected territories.

\section{Austria: country analysis and case study}

\subsection{Demographic dynamics and migration flows}

Rural regions and mountain territories represent more than two thirds of Austria's surface. These areas are characterised by various demographic and economic developments, which are mainly connected to emigration and to a progressive ageing of the local population. International but also internal migration has so far been mainly linked to cities or urban regions (Bender and Kanitscheider, 2012; Woods, 2016).

A turnaround in demographic development can be observed: seasonal jobs and employment in tourism, agriculture, mining and manufacturing are indeed attracting international labour force in rural regions (Machold and Dax, 2015). Especially over the last two decades, war clashes linked to the dissolution of the former Yugoslavia or the Soviet Union as well as the opening of the former COMECON states to the east of Austria and to the EU enlargement to the East (since 2004) have triggered migration flows.

Foreign citizens are generally much younger than Austrian ones: in 2012 a quarter of Austrians had already passed 60 years. Conversely, among foreigners, the number of people aged over 60 amounted to only about 10\% (Machold and Dax, 2015). 
Mainly because of the strong migratory flows that have been registered since 2015, a group of mayors of Austrian municipalities has recently set up a working group aimed to stimulate the exchange of practices dealing with the reception of asylum seekers (Forum Alpbach, 2016). This initiative highlighted that the reception of further asylum seekers is feasible but under the condition of being adequately managed at the local level. However, the relevance of both migratory flows and social diversity have been recognised so far only sporadically as an argument for regional policy designed to support rural regions.

The programmes and project initiatives that recognise international and forced migration as a chance for the revitalisation of remote and rural regions are expanding in Austria. These projects are giving migrants and long-term residents, including refugees and status holders, the opportunity to participate in village and regional life, for instance through the delivery of training to learn the language of the hosting community, individual support to find job opportunities ${ }^{8}$, and by creating opportunities to be involved in social life. This with a view to harness the potential of migrants and to strengthen, in this way, the rural regions, which lack manpower and experience emigration of young people and ageing. Hence, the main purpose is to stabilise the number of inhabitants in remote areas and the delivery of basic general interest services, including welfare, health, educational and proximity services, otherwise at risk of survival (Hagspiel, 2016; Fachhochschule Kaernten, 2017; BLE, 2017).

\subsection{Asylum seekers, refugees and status holders: Reception conditions and integration}

In Austria, asylum seekers are dispersed throughout the country according to a quota system based on the population of each federal province. Nevertheless, the Ministry of Interior can decide to open reception facilities in federal provinces that do not fulfil the reception quota. Both the needs of special target groups (unaccompanied minors, single women and disabled persons) and family ties are taken into account when distributing recipients. However, asylum seekers have in practice almost no possibility to choose the place where they will be accommodated and they are only allowed to reside in the federal province assigned to them.

Significant variations in reception capacities exist across Austrian provinces: while the province of Vienna offers many more reception places than those foreseen by the quota system, other provinces have failed to provide enough places for several years.

For the management of reception centres, the governmental departments of the respective federal provinces contract either third sector organisations or private for-profit providers: contracts to specify the number of asylum seekers to be accommodated and the basic social services to be provided.

Overall, at the end of 2017, there were 26 federal reception centres, which hosted 1,692 persons. These include reception centres where catering is provided, reception centres

\footnotetext{
${ }^{8}$ For example, the initiative of the Public Employment Service (AMS) and the Austrian Federal Economic Chamber (WKO) to connect young refugees and status holders with apprenticeship options in all federal provinces, including in rural areas (OECD, 2018b).
} 
where asylum seekers take care of cooking, and privately- rented accommodation. Based on the type of accommodation, the compensation awarded to recipients differs ${ }^{9}$.

According to the Basic Care agreement between the State and the federal provinces, the latter have to cover $40 \%$ of the expenditures, while the Ministry has to pay $60 \%$ of the costs.

\subsection{Economic and social integration}

A labour market test restricts asylum seekers' access to the labour market. This test requires proof that the respective vacancy cannot be filled by either an Austrian citizen, a citizen of the EU or a legally residing third-country national with access to the labour market. Applications for an employment permit must be submitted to the regional Labour Market Service (AMS) office in the area of the district where the envisaged place of employment is located. The competent regional AMS office is responsible for taking the decision.

A 2004 ordinance provides for further restrictions, by limiting employment to seasonal work either in tourism, agriculture or in forestry according to a quota for each federal province and this permission can only be issued for a maximum period of 6 months. A further problem for asylum seekers working as seasonal workers is that receiving a salary triggers the duty to contribute to the Basic Care.

The following section analyses the case of a municipality located in the TL3 region Klagenfurt-Villach: Weitensfeld im Gurktal. It illustrates the difficulties to integrate asylum seekers that are faced at the local level when local development policies and integration strategies are lacking altogether, evidencing a disconnection between different levels of governance (Piccinni and Proietti, forthcoming).

\subsection{Klagenfurt-Villach: the Municipality of Weitensfeld}

Klagenfurt-Villach is an Alpine region located at the South-East of Austria. This region shares its Southern border with Slovenia and Italy (Friuli-Venezia Giulia and its Northern border with two other TL3 Austrian regions, namely Oberkärnten and Unterkärnten, which are both predominantly rural regions. Klagenfurt-Villach has a total of 283.941 inhabitants ${ }^{10}$. Its main urban centres are Klagenfurt am Wörthersee (100.000 inhabitants)

\footnotetext{
${ }^{9}$ Basic Care may be provided in three different forms: 1) Asylum seekers can be accommodated in reception centres where catering is provided. Asylum seekers in such reception centres receive $€ 40$ pocket money per month, while the care provider (NGOs, private companies contracted by the Government) receives $€ 21$ maximum compensation for the costs per day, depending on the standards of the facility. 2) Basic Care can be provided in reception centres where asylum seekers cook by themselves. In that case, asylum seekers receive between $€ 150$ and 200 per month. 3) Basic Care can be provided for asylum seekers in private rented accommodation. In this case, asylum seekers receive between $€ 320$ and 365 per month in cash. All asylum seekers receive additionally $€ 150$ a year for clothes in vouchers and pupils get $€ 200$ a year for school material, mainly as vouchers. Asylum seekers living in private rented flats receive $43 \%$ of the needs-based minimum allowance for citizens in need of social welfare support, which is about $€ 860$ per month. At the end of 2017, 1.692 persons received Basic Care in federal reception centres.

10 Data retrieved from JOANNEUM RESEARCH - Institut für Wirtschafts- und Innovationsforschung (POLICIES), updated January 2018 (data 2016). Available at: https://wibis.kwf.at/fileadmin/user_upload/wibis_kaernten/regionsprofile/201801.2/AT211_PROFIL_2_Daten_25.01.2018.pdf
} 
and Villach (61.887) and are connected to the other smaller centres (with an average population of 1.000 people each) by a railway line and a bus service ${ }^{11}$.

Recent data on the economy of the region (2018) are available only for the federal province (TL2) in which Klagenfurt-Villach is located: Carinthia. Carinthia has an unemployment rate which is rising but it is still lower than the national average (5.4\% compared to the $6 \%$ national average in 2017) and a lower GDP growth, since 2000, compared to the average of Austria's federal states (European Commission, 2017). Carinthian inhabitants are mainly employed in agriculture (5.1\%), manufacturing $(24.5 \%)$ and services $(70.4 \%)^{12}$.

The presence of foreigners in Carinthia is the lowest in Austria; only $7.3 \%$ of residents are foreign born, with a particularly low percentage of third country nationals ${ }^{13}$ who are mainly located in the biggest urban centres.

This case study focuses specifically on the Municipality of Weitensfeld im Gurktal, a remote Carinthian town ${ }^{14}$ of 2.155 inhabitants located in the valley Gurktal, which is facing a depopulation trend and scarce job opportunities. Weitensfeld has hosted asylum seekers since 2014. The owner of the Gasthof Bärenwirt, who currently hosts the highest number of asylum seekers in the municipality, and the mayor of Weitensfeld encouraged the arrival of asylum seekers.

\begin{tabular}{|l|l|}
\hline Territorial challenges & Territorial resources \\
\hline $\begin{array}{l}\text { Progressive decline and } \\
\text { ageing of the rural } \\
\text { population }\end{array}$ & $\begin{array}{l}\text { Arrival and prolonged stay } \\
\text { of asylum seekers since } \\
2016\end{array}$ \\
\hline $\begin{array}{l}\text { Scarcity of services for } \\
\text { rural districts with low } \\
\text { levels of tourism }\end{array}$ & $\begin{array}{l}\text { Possibility to re-launch the } \\
\text { supply of touristic services } \\
\text { by integrating migrants in } \\
\text { the touristic sector }\end{array}$ \\
\hline $\begin{array}{l}\text { Scarcity of job } \\
\text { opportunities both for } \\
\text { natives and foreign-born } \\
\text { residents in rural and } \\
\text { remote areas }\end{array}$ & $\begin{array}{l}\text { Multinational enterprises } \\
\text { including tech industries } \\
\text { (e.g., Siemens) close to } \\
\text { cities }\end{array}$ \\
\hline
\end{tabular}

\footnotetext{
${ }^{11}$ Bus and railway services are relatively expensive in relation with the money provided to asylum seekers under the Austrian Basic Care support measures (40€ if meals and accommodation is provided to them), especially with regard to asylum seekers that live far away from the main cities of the land where schools and services are mainly located.

${ }^{12}$ https://ec.europa.eu/growth/tools-databases/regional-innovation-monitor/base-profile/carinthia (accessed 20 April 2018)

${ }^{13}$ http://www.plattform-migration.at/index.php?id=343\&L=1 (accessed 21 April 2018).

${ }^{14}$ According to Statistics Austria (2018), based on a national urban-rural typology based of Austrian municipalities, Weitensfeld im Gurktal is classified as a peripheral rural area (430).
} 


\begin{tabular}{|l|l|}
\hline $\begin{array}{l}\text { Lack of local development } \\
\text { and integration strategies, } \\
\text { especially in rural remote } \\
\text { territories }\end{array}$ & $\begin{array}{l}\text { Growing policy } \\
\text { commitment of mayors of } \\
\text { rural remote municipalities } \\
\text { to boost local development }\end{array}$ \\
\hline $\begin{array}{l}\text { Low propensity of citizens } \\
\text { to self-organise, except for } \\
\text { confessional associationism }\end{array}$ & $\begin{array}{l}\text { Potential engagement of } \\
\text { renown persons (mayor, }\end{array}$ \\
& $\begin{array}{l}\text { local entrepreneurs) who } \\
\text { could mobilise the local } \\
\text { community }\end{array}$ \\
\hline
\end{tabular}

\subsection{Welcoming asylum-seekers: the Gasthof Bärenwirt}

In Weitensfeld, the owner of a Gasthof doomed to closure started the welcoming of asylum seekers: Gasthof Bärenwirt. Driven by a humanitarian concern, the owner decided to keep the Gasthof open to accommodate asylum seekers. The building can host up to 20 asylum seekers and the owner has hired three other people (part time) to help her with the everyday management of the house. Currently only 14 guests are present in the Gasthof due to the general decline in numbers of asylum requests in Austria. Almost 150 asylum seekers have stayed at the Gasthof so far, all of them coming from the Middle East - e.g. Afghanistan, Iran, Iraq, Syria, but also stateless Kurds - as expressly requested by the owner to the Carinthian authority in charge of managing asylum seekers. The goal of the Gasthof reception project is to exploit to the fullest the possibility of asylum seekers to mingle with the local population, especially through the restaurant and bar, which are open not only for the local regular customers but also for occasional tourists. Indeed, the restaurant of the Gasthof offers to asylum seekers the possibility to sometimes cook and teach new recipes that can be experimented by the restaurant's chef. This, in turn, gives the opportunity to locals to taste new dishes and mingle with the hosts and to asylum seekers to explain their culture and background through food.

In order to make sure that the conditions for the arrival of asylum seekers were at their best, the mayor prepared the local community, supported by the local churches (i.e. Catholic, Protestant and the Free Churches). To ensure that the support of the community towards the integration of the asylum seekers hosted remained unfaltering, in 2015 and 2016 the Gasthof organised parties, events and workshops for asylum seekers and local population alike. This brought the attention of the media and the Gasthof Bärenwirt became part of a national network of good practices in asylum seekers reception: the Network Allianz "Menschen. Wurde. Osterreich" 15 . The reception project of the Gasthof is also part of a local network in which asylum seekers' hosts support each other not only in bureaucratic processes but also in social and emotional hurdles. However, this local network does not pull resources together to create opportunities for integration and every action taken in this direction is mainly based on personal commitment.

In 2017, the Gasthof Bärenwirt received $19 €$ per day per asylum seeker to provide food and accommodation and to ensure that asylum seekers could follow German language and Austrian culture courses. No costs of courses and activities other than language courses including vocational training and sports, which would be beneficial for integration - are covered by this sum. Asylum seekers staying at the Gasthof Bärenwirt receive $40 €$ per

15 https://www.mwoe.at/impressum/ (accessed 24 April 2018). 
month from the Carinthia state to cover any other necessity, including transportation to reach the closest city and legal support. Indeed, asylum seekers staying at the Gasthof do not receive any free legal or psychological support, with the exception of the presence of a social worker sent by the government of Carinthia for a couple of hours every week to provide answers to the most urgent requests and needs of asylum seekers.

\subsection{Impact upon the local community and recipients}

Overall, the reception of asylum seekers prevented the closure of the Gasthof and enabled the Municipality of Weitensfeld to benefit from additional resources coming from the national government, consistently with the number of recipients hosted ${ }^{16}$. This initiative offered also to local inhabitants the possibility to benefit from exchanges with foreign cultures ${ }^{17}$.

At the same time, asylum seekers recognise the trainings and the workshops at the Gasthof together with the opportunities they have to socialise with Austrians, as crucial for their paths towards independence and as a way to forge trust relations with local inhabitants.

So far, the outcomes of this project in terms of regeneration of the local territory and community are rather modest: no new activities were started drawing on the skills of recipients and out of over 100 asylum seekers, only one family, guest of the Gasthof Bärenwirt, managed to settle down in Weitensfeld: the head of the family works as a baker and the owner of the Gasthof helped the family find accommodation through her personal linkages.

According to the Mayor of Weitensfeld this situation is mainly due to the lack of job opportunities and public investments in a rural area with a depopulation trend: this creates further tensions between the local population and asylum seekers. This is reflected in the attitude of the local population, which has shifted very recently from being openly in favour of the presence of asylum seekers to being moderately hostile in 2017 , even though no traumatic events involving asylum seekers hosted in the area have taken place since their arrival. Local actors attribute the shift to the national electoral campaign and partly also to the increasing media attention on the issue of refugees and asylum seekers, especially after the Cologne (Germany) incidents of 2016.

An additional major obstacle jeopardising the prospects for integration of asylum seekers is the legal status insecurity and the prolonged asylum procedure. In Carinthia, asylum seekers have a waiting period of over two years before their first interview with the commission that decides on their protection status. This situation affects the majority of the hosts of the Gasthof Bärenwirt, who also claim that they are not incentivised to integrate the asylum seekers as the possibilities to work and to become active members of the local community start only with the recognition of the protection status. Moreover, recipients are overall afraid of what might happen in case of denial of the subsidiary protection or refugee

\footnotetext{
${ }^{16}$ Interview with the Mayor of Weitensfeld (17 April 2018). As of April 2018, there are 22 asylum seekers in Weitensfeld im Gurktal.

${ }^{17}$ According to Weitensfeld's School Director, in the last five years, the local school of Weitensfeld has had among its students five third country nationals. For them, the school organizes a special German language programme to help them keep up with the other students. For the whole school, instead, the director together with the teachers have been organizing special cooking classes where traditional Austrian dishes are mixed with foreign flavours and foreign cultures classes (every Friday). Moreover, every two years the school organizes an Action Tag: a cultural event open to families and local community where students describe and explain foreign cultures.
} 
status, as they hear stories of deportation (e.g. to Afghanistan) after spending two or more years learning the German language and Austrian values.

This aspect, combined with the de facto impossibility for asylum seekers to work or start a traineeship, including vocational training, jeopardises their early access to the labour market (OECD, 2016; OECD/EU, 2015).

Finally, according to the very few associations operating in Weitensfeld and in the neighbouring towns, additional factors explaining the low ability of the public and private local actors to take adequately stock of the skills and talents of asylum seekers include the low propensity of the local population to self-organise and the low level of trust.

\section{Germany}

\subsection{Demographic dynamics and migration flows}

Following the recent analysis of the Federal Ministry of Food and Agriculture, rural areas are expected to face a growing de-population trend ${ }^{18}$. To anticipate this trend, the Federal Rural Development Scheme designed an innovative development strategy in 2015 aimed at both keeping rural regions attractive and supporting structurally disadvantaged regions.

In addition, the model project "Land(auf)Schwung" ("Rural upswing"), funded through the regional budget and addressed to rural regions with a structural disadvantage, supports specifically entrepreneurs presenting innovative development projects for the region.

Recent research has been conducted in the rural districts of Freyung-Grafenau and Regen, situated alongside the border with Austria and the Czech Republic (Weidinger, 2018), in order to identify different trends of international migration towards the rural areas. Both these districts are part of the low mountain range area called the Bavarian forest, a famous tourist destination in Germany renowned for its national park. In line with the national classification published by the German Thuenen-Institute (Kuepper, 2016), both districts can be categorised as "very rural".

Finally, with its national programme "500 Land Initiatives" the Federal Ministry of Food and Agriculture is explicitly aiming to support volunteer work in rural regions. The programme focuses on initiatives promoting the sustainable integration of refugees in rural areas and is part of the Federal Rural Development Scheme ${ }^{19}$.

\subsection{Asylum seekers, refugees and status holders: Reception conditions and integration}

Germany has received the highest influx of asylum seekers in Europe since 2012 and has implemented spatial dispersal policies ever since (Eurostat, 2018b). According to the spatial dispersal principle, asylum seekers in Germany are, thus, accommodated both mandatorily and voluntarily in rural areas during their asylum procedures. It must be noted that asylum seekers are not allowed to leave their state accommodation until they have been granted protected status. Then, they can freely decide where to live and whether they want to remain in remote and rural areas or move to urban areas.

\footnotetext{
${ }^{18} \mathrm{https}: / /$ www.bmel.de/EN/RuralAreas/_Texte/DemografieWandel.html;jsessionid=685100BC226 8787DEB8B907095617292.1_cid367?nn=313232rea?

${ }^{19} \mathrm{https://www.500landinitiativen.de/}$
} 
Asylum policies and the administration of asylum are not homogenous across Germany: the federal states have several competences and, therefore, various ways of influencing admission policies and, more specifically, the living conditions of asylum-seekers (Piccinni and Proietti, forthcoming). Asylum seekers, who enter the Federal Republic of Germany or who are in the country without a residence permit, are transferred to the nearest reception centre of the federal state that they are in. This initial distribution of asylum-seekers is done by the dispersal system known through the acronym EASY (Erstverteilung von Asylbegehrenden). The EASY general distribution system usually determines the place of residence of asylum seekers; places for asylum seekers are at first allocated to the Federal States for the initial reception period and to the municipalities within the Federal States afterwards.

With the exception of Saarland and Bavaria, all German federal states have transferred the responsibility of providing accommodation to local municipalities, who can decide at their discretion whether the management of the centres remains in charge of local municipalities themselves or whether this task is transferred to third sector organisations or to facility management companies.

Every new asylum seeker has to stay from three to six months in the initial reception centre, subject to a certain restrictions. The following aspects determine the distribution of asylum seekers: a) capacities of initial reception centres; b) competence of the branch offices of the BAMF regarding the applicant's country of origin; c) a quota system called "Königsteiner Schlüssel", according to which reception capacities are determined for Germany's 16 Federal States. The Königstein Schlüssel takes into account the tax revenue (accounting for $2 / 3$ of the quota) and the number of inhabitants (1/3) of each Federal State.

In general, three types of accommodation for asylum seekers can be distinguished: a) initial reception centres, including particular types of centres such as arrival centres, special reception centres and transit centres; b) collective accommodation centres; c) decentralised housing model. Emergency shelters were used in particular in 2015 and 2016 but most of them closed down in 2017.

According to the "geographical restriction", asylum seekers are obliged to stay in the district to which they have been allocated for the whole duration of their procedure. The Federal States are entitled by law to organise the distribution and the accommodation of asylum seekers within their territories.

Assistance under the Asylum Seekers' Benefits Act generally consists of "basic benefits", such as a fixed rate supposed to cover the costs for food, accommodation, heating, clothing, personal hygiene and consumer goods for the household ${ }^{20}$.

\footnotetext{
${ }^{20}$ Allowances for asylum seekers (from 1 January 2018 onwards) are 135 euros/month for a single adult in accommodation centres, while 354 euros/month if he/she lives outside: reduced amounts of money are provided to the partner and to every member of the household. Asylum seekers, who are accommodated in reception or accommodation centres, generally have to be provided with the necessary means of food, heating, clothing and sanitary products in these centres. Therefore, the rates for these groups are considerably lower than they are for asylum seekers living in apartments of their own. For those living outside the accommodation centres, the costs for accommodation (rent), heating and household goods have to be provided on top of the allowances.
} 


\subsection{Economic and social integration}

Until 2014, asylum seekers' access to the labour market was restricted to up to five years. In November 2014, this provision was changed, and asylum seekers can now enter the labour market after three months.

Access to the labour market is however granted with restrictions. First, when applying for an employment permit, asylum seekers have to prove that there is a "concrete" job offer, and they have to provide to the authorities a detailed job description. Secondly, for a period of 15 months following the registration of the asylum application and the issuance of the Aufenthaltsgestattung, the job centre usually has to carry out a "priority review". This is an examination of whether there is another suitable job seeker for the offered position, who also has a better status in terms of employment regulations, for instance another German citizen or a foreigner with a secure residence permit.

Asylum seekers are not allowed to work on a self-employed basis for the whole duration of their asylum procedure, since the permission to pursue self-employment depends on a regular residence title.

In Germany, a new integration law was introduced in 2016, which includes a three-year local connection rule for refugees or status holders who received their recognition after January 1st, 2016 and who do not have a job or an apprenticeship. This specifies that the place of residence must be located within the federal state where the refugee was already accommodated during his or her asylum procedure (§12a par. 1 AufenthG).

The next case study explores the case of an intercommunal alliance of municipalities that has embarked on a welcome project as part of a wider local development strategy.

\subsection{Haßberge: Hofheim Land}

Hofheim Land is an intercommunal alliance of municipalities located in Haßberge, a Bavarian Landkreis (TL3 ${ }^{21}$ ) in the northern part of Bavaria, Germany, which includes 26 municipalities. It is bounded by the districts of Coburg, Bamberg, Schweinfurt and RhönGrabfeld, and by the federal state of Thuringia. As a district, it was established in 1972 by merging the districts of Hassfurt, Ebern and Hofheim.

The total population living in Haßberge district, defined by OECD typology as "predominantly rural close to a city", amounts to 85,900 inhabitants out of whom $52 \%$ live along the Main river in the southern part. Since 1970, the population has declined progressively. Of particular concern are the decline of birth rates and the progressive outmigration of youth (aged 18-24) and of women, who leave Haßberge district to search for better living conditions elsewhere. The demographic deficit is expected to worsen over the next years. Noteworthy is the expected population decrease of the major town of Hofheim by $7.4 \%$ between 2014 and $2034^{22}$. The loss in working population results in severe labour shortages especially in the services sector and in a decrease of pupils, which hampers the survival of local schools. This said, in the more peripheral municipalities of Hofheimer Land the expected decrease in population is estimated to be even higher.

\footnotetext{
${ }^{21}$ OECD regional typology 2018.

22 Data retrieved from the website of Intercommunal Alliance Hofheimer Land. Available at: http://www.hofheimer-land.de/index.php?id=66. See also: https://www.statistik.bayern.de/statistikkommunal/09674.pdf and https://www.statistik.bayern.de/statistikkommunal/09674149.pdf
} 


\begin{tabular}{|l|l|}
\hline Territorial challenges & Territorial resources \\
\hline $\begin{array}{l}\text { Progressive decline and } \\
\text { ageing of the local } \\
\text { population }\end{array}$ & $\begin{array}{l}\text { Arrival and prolonged stay } \\
\text { of asylum seekers since } \\
2014\end{array}$ \\
\hline $\begin{array}{l}\text { Growth in number of } \\
\text { economic and social } \\
\text { concerns affecting the local } \\
\text { territory (i.e. obsolete and } \\
\text { scarce public transport } \\
\text { networks) }\end{array}$ & $\begin{array}{l}\text { Structured and effective } \\
\text { cooperation through the } \\
\text { intercommunal alliance of } \\
\text { municipalities }\end{array}$ \\
$\begin{array}{l}\text { Association Hofheim Land } \\
\text { in different domain of } \\
\text { interest to the community } \\
\text { including welcome and } \\
\text { integration of migrants) }\end{array}$ \\
\hline $\begin{array}{l}\text { Out-migration of youth and } \\
\text { labour shortages }\end{array}$ & $\begin{array}{l}\text { Willingness to integrate } \\
\text { refugees to work by } \\
\text { matching the demand of } \\
\text { local firms with the supply } \\
\text { of work of recipients }\end{array}$ \\
\hline $\begin{array}{l}\text { Increase in number of } \\
\text { abandoned, unused } \\
\text { buildings and spaces }\end{array}$ & $\begin{array}{l}\text { Availability of funding } \\
\text { schemes tailored to } \\
\text { finance the renovation of } \\
\text { old houses and support } \\
\text { innovative investments in } \\
\text { the domain of local } \\
\text { development re-adjusted } \\
\text { for integration purposes }\end{array}$ \\
\hline
\end{tabular}

\subsection{Tackling the asylum challenge: welcoming asylum-seekers in the remote Haßberge region}

The arrival of asylum seekers in Haßberge region in 2014 has been among one of the several challenges the rural territories of Northern Bavaria had to deal with over the last decade. Nonetheless, their decision to seize the arrival of newcomers as an opportunity rather than a threat builds on the challenging collective effort made by the seven municipalities located in the northern Landkreis Haßberge. Those municipalities agreed to tackle together a number of social and economic concerns connected to the decline of the population and out-migration of a significant number of local inhabitants.

The search for an alternative development path had already started in 2008, when a common funding programme for the revitalisation of empty and abandoned buildings was initiated. Afterwards, the municipalities of Aidhausen, Bundorf, Burgpreppach, Ermershausen, Hofheim, Maroldsweisach, and Riedbach in the northern part of the district embarked on a common development strategy supported financially by the State of Bavaria. This strategy focused on a number of policy domains that are of particular concern 
for the local communities: local supply of services, rural economic development, housing and construction, welfare, tourism, regional identity and mobility ${ }^{23}$.

A public support scheme tailored to improve living conditions resulted in the modernisation old houses, investments in technology to support agricultural development and installation an optic fiber to provide internet connection. Most importantly, the creation of the Hofheim Land Association in 2008 formalised the informal cooperation among the seven abovementioned municipalities.

In 2014, the first 17 asylum seekers were assigned to the territory covered by Hofheim Land Association, followed by 153 recipients who were welcomed in the same area in 2016. Moreover, in 2016 Hofheim Land Association created a full time job position for a coordinator of asylum issues in order to strengthen networking among various stakeholders (relief centres, local inhabitants, volunteers, recipients, enterprises). The association welcomed the asylum seekers in cooperation with the relief centre and its volunteers operating in the same areas. The association and the relief centre offered to the asylum seekers basic care and accommodation in 20 dispersed houses and introduced them to their new hosting communities.

The first discussions about the asylum issue had started earlier: in September 2013, the City of Hofheim appointed Prof Uhlich as "Delegate for Asylum Issues". Later, a refugee relief organisation "Freundkreis Asyl Hofheim" was founded by volunteers. Over the years, this association has evolved into an exemplary citizens' initiative that endeavours to successfully support the integration of asylum seekers in receiving communities, while tackling key challenges faced by receiving territories in cooperation with the Hofheim Land Association. The association counts now 65 members, who provide support to approximately 90 asylum seekers and refugees ${ }^{24}$.

Drawing on the perceived need to nourish a welcome culture and help recipients integrate in receiving communities, the coordinator in charge of asylum issues and the association Freundkreis Asyl Hofeim identified key persons in charge of tackling critical domains (education, homecare, use of technical equipment, waste separation). The association started to organise regularly intensive German language classes, traffic safety classes, and sport activities. Moreover, the relief centres that cooperate with the association continued to organise regular multicultural meetings and evenings together with asylum seekers.

A number of key strategies shared jointly by the Hofheim Land Association and the association Freundkreis Asyl Hofheim contribute to explaining their successful endeavour when compared to other rural territories, which conversely failed to manage the asylum challenge effectively and were overwhelmed by local inhabitants' hostile reactions ${ }^{25}$. Indeed, a growing number of recipients have decided to settle down in Hofheim and its surroundings.

The active engagement of key renowned persons, who are well respected by local inhabitants, in the welcome process was of crucial importance. These included the former delegate for asylum issues, the mayor of Hofheim, the city council, the priest, the church community, the local authorities, as well as the local entrepreneurs, artisans, local businesses, and sport and cultural associations. In this respect, the mayor of the village of

\footnotetext{
${ }^{23} \mathrm{http} / /$ www.hofheimer-land.de/index.php?id=startseite

${ }^{24}$ Data retrieved from Asylfreunde Hofheim: http://www.asylfreunde-hofheim.de/DE/start.htm

${ }^{25}$ Data retrieved from Asylfreunde Hofheim: http://www.asylfreunde-hofheim.de/DE/start.htm
} 
Hofheim, who has long been concerned about Hofheim's dwindling population, played a key role in convincing the local population that the influx of asylum seekers should be regarded as an opportunity (Uhlich and Moering, 2016; Weidinger, 2018).

The involvement of a significant portion of the local population in the welcome process by the association Freundeskreis Asyl Hofheim played a key role: the preparation of the local community towards the arrival of newcomers contribute to shifting the perception of the local population towards asylum seekers and to promoting a welcome culture.

\subsection{Impact upon the local community and recipients}

What is special in the case of Hofheim Land is that measures, which were initially designed for rural development, were successfully reused for asylum purposes, turning Hofheim Land in an exemplary integration laboratory for migrants.

Thanks to the arrival on newcomers, old unused buildings were repurposed for the accommodation of asylum seekers. This enabled to revitalise rural abandoned spaces that would not have otherwise been exploited for welfare purposes. Furthermore, rural populations living on this territory can learn about the factors driving people to flee their homes through inter-cultural exchanges with newcomers and their personal stories (Rhein, 2017). Thematic cultural evenings focused on "Afghanistan" or "Syria" have been very well attended and appreciated. In this respect, the active involvement of the local population with a view to agree on common strategies on how to manage the asylum challenge spurred the active engagement of the same asylum seekers, who volunteered to support some of the activities carried out by the association Freundkreis Asyl Hofeim and who joined it as members in some cases.

The willingness of migrants to settle down in Hofheim suggests that local actors (local administrations, policy makers, the educational sectors and civil society) have a role to play when it comes to the residential location choice of refugees and status holders in favour of rural areas (Weidinger, 2018). Key factors influencing migrants' decision to settle in Hofheim include the support provided by both the local population and the Association of Hofheim Land.

Nevertheless, once learned the language and obtained the protection status, finding a suitable accommodation and a stable job remain the key challenges to be faced by asylum seekers, refugees and status holders, who are willing to settle in in this territory.

The Hofeimer Land Association is in this respect at the forefront both by facilitating the matching of the labour shortages of the local enterprises with the labour supply of refugees and status holders and by helping recipients find a stable accommodation. The additional availability of labour force supplied by asylum seekers could indeed meet the labour shortages that key economic sectors are facing due to the out-emigration of youth. The asylum coordinator currently undertakes an assessment of job skills supply and demand of locals firms (matching) in order to improve the functioning of the local labour market.

The number of status holders and refugees who have so far decided to settle down in the territory of the Hofheimer Gemeindeallianz is significant: out of the current 120 inhabitants with refugee background 25 have a work contract. Nine out of 25 have professional formation contracts (Ausbildungsverträge). Nine family reunifications have been finalised so far. 


\section{Italy}

\subsection{Demographic dynamics and migration flows}

In Italy, remote areas are mainly mountain territories located in the Alps and Apennines ${ }^{26}$.

After more than a century of demographic decline many sectors of the Alpine crescent are now experiencing a reversal trend (Corrado, 2010; Perlik, 2011; Viazzo, 2012; Mathieu, 2015; Zanini, 2016), which is predominantly due to a positive net migration. Positive migratory balances compared to other EU countries were recorded in the past decade almost everywhere in the Italian Alps and concentrations of certain nationalities in particular territories are noticeable (Corrado, Dematteis and Di Gioia, 2014).

According to data provided by Istat (the Italian Institute for Statistics) and by the Alpine Convention, on January 1st, 2014 the number of foreign residents in the 1,749 Italian Alpine municipalities amounted to about 350,000 people, almost equally divided between males and females and mostly coming from Romania or non-EU countries.

Although migration for economic purposes appears by now to have become a structural feature of the mountain and rural Italian society, over the last years, Italy has turned into an arrival destination for new migration flows, mostly comprised of people fleeing war, natural disasters or intolerable socio-political conditions. Recent research shows the important role mountain areas play in providing reception to asylum seekers, when compared to the rest of the Italian territory (Dematteis, Di Gioia and Durbiano, 2017). In fact, the Alpine municipalities have welcomed $10 \%$ and the Apennine municipalities $30 \%{ }^{27}$ out of the 125,203 asylum-seekers registered in July 2016.

Two distinct types of territories can be identified. The first type, which is facing a contextual long-standing demographic loss and socio-economic crisis, is composed of municipalities that are experiencing the recent arrival of asylum seekers. The second type, which has registered a positive migration balance over the last years, refers to mountain territories that are considered attractive for new inhabitants.

\subsection{Asylum seekers, refugees and status holders: Reception conditions and integration}

In Italy, there is no uniform reception system ${ }^{28}$. Upon arrival, asylum seekers and migrants may be placed in the following first reception centres: a) first Aid and Reception Centres

${ }^{26}$ They are defined as "internal areas" by the Strategia Nazionale Aree Interne - SNAI. This is a national and governmental strategy, aiming at supporting local development in rural and mountain territories: http://www.agenziacoesione.gov.it/it/arint/

${ }^{27}$ A significant number of mountain municipalities surmount the $2.5 \%$ threshold of migrants per thousand inhabitants that ought to be welcomed, based on the recently been defined National Government's objectives. The availability of empty or under-used structures is the main reason explaining the temporary accommodation of migrants in mountain areas.

${ }^{28}$ LD 142/2015, which articulated the reception system in phases was replaced on December 1, 2018 by Law n. 132. The different phases of reception remain, distinguishing betweenas such: a) phase of first aid and assistance, operations that taketaking place in the centres set up in the principal places of disembarkation; b) first reception phase, for asylum seekers only, to be implemented in existing collective centres or in centres to be established by specific Ministerial Decrees or, in case of unavailability of places, in "temporary" structures (CAS); c) second reception phase, only for 
(CPSA), created in 2006 for the purposes of first aid and identification before transferred to other centres, and now formally operating as "hotspots"; b) collective centres: this includes the centres previously known as governmental centres for accommodation of asylum seekers (CARA) and accommodation centres (CDA); c) Temporary Reception Centres (CAS), implemented by Prefectures in case of unavailability of places in the first or second accommodation centres and run by a myriad of different private entities. The law does not specify any time limit for the stay of asylum seekers in these centres. Applicants' freedom of movement is affected by the impossibility to leave the reception centre temporarily, for example to visit relatives without prior authorisation (Piccinni and Proietti, forthcoming $[15]$; OECD, 2018a).

Depending on the availability of places, asylum seekers can be placed in centres across the national territory, and after their initial allocation they may be moved from one centre to another, be it for organisational necessities, disciplinary concerns and even for the manifestations of discontent from the local population.

First reception centres accommodate high numbers of asylum applicants and offer basic services such as food, accommodation, clothing, basic information services including legal services, first aid and emergency treatments ${ }^{29}$. On 26 September 2017, the Ministry of Interior published the National Integration Plan for beneficiaries of international protection. It specifies that, until the SPRAR becomes the only second-line reception system, temporary first reception facilities (CAS) need to align the quality of their services and activities (such as language courses) to those offered by the SPRAR centres. Local authorities together with third sector organisations run SPRAR centres. More precisely, they ensure interpretation and linguistic-cultural mediation services, legal counselling, teaching of the Italian language, access to schools for minors, health assistance, sociopsychological support in particular to vulnerable persons, training and re-training, support at providing employment, counselling on the services available at local level to allow integration locally, information on (assisted) voluntary return programmes, as well as information on recreational, sport and cultural activities.

With the entry into force of Law n.132/2018, converting DL n.113, also known as "Decreto sicurezza" or "Decreto Salvini", from the name of Italy's Minister of the Interior, asylum seekers will not be hosted in SPRAR centres but only in CAS and other first reception facilities. Moreover, CAS and first reception centres will not be required to align their standards to SPRAR centres, since the new law does not provide for any integration services for asylum seekers.

In addition to the abovementioned reception centres, noteworthy is also a network of private accommodation structures, which are not part of the national reception system ${ }^{30}$.

refugees and holders of international protection status (excluding humanitarian protection), carried out in the structures of the what was called SPRAR system (formerly system of protection for asylum-seekers and refugees, now only for refugees, run by municipalities and other local actors) ( in italics the changes introduced with the new law).

${ }^{29}$ Asylum seekers hosted in first reception centres receive $€ 2.50$ per day per person as pocket money. Pocket money in CAS is agreed with the competent Prefecture but the amount received by applicants hosted in CAS should be $€ 2.50$ per day per person and up to $€ 7.50$ for families. Persons hosted in a SPRAR centre receive a pocket money, which varies depending on the individual project from $€ 1.50$ to $€ 3$ with up to $20 \%$ reduction for families exceeding two people.

${ }^{30}$ Accommodation is provided for example by Catholic or voluntary associations: on April 2017, over 500 families in Italy were hosting a refugee. 
As reported by Medici Senza Frontiere (MSF) in February 2018, the reception system excludes at least 10,000 asylum seekers, refugees and status holders. Informal settlements with limited or no access to essential services are spread across the entire national territory, namely in Ventimiglia, Torino, Como, Bolzano, Udine, Gorizia, Pordenone, Rome, Bari and Sicily.

\subsection{Economic and social integration}

According to LD 142/2015, asylum applicants can start to work within 60 days from the moment they lodged the asylum claim. Following this rule, SPRAR centres and a certain number of CAS centres used to offer regularly vocational training. Nevertheless, opportunities to access integration programmes varied to a significant extent, depending on the location of the accommodation of the asylum seekers. Even though the law made a generic reference to the right to access to employment without indicating any limitations and asylum seekers have the right to enlist into Provincial Offices for Labour, in practice they face serious difficulties in registering to the Municipality, such as the bureaucratic requirement to enrol in job placements and to obtain a residence permit. This is due either to delays in the registration of their asylum claims, on the basis of which the permit of stay is issued, or to delays in their renewal due to bureaucratic backlogs.

The Law n. 132/2018 radically changes the system of integration of asylum seekers and holders of humanitarian protection status. With this reform, SPRAR centres will no longer host both asylum seekers and holders of humanitarian protection status. SPRAR centres will instead continue to host and provide integration support measures for refugees and holders of subsidiary protection status. Therefore, asylum seekers and holders of humanitarian protection are no longer entitled to receive support for their integration process.

A case study of a social cooperative that successfully managed the asylum challenge is discussed below. This social cooperative succeeded in facilitating the integration of asylum seekers, refugees and status holders and paved the way for further development opportunities for the host community.

\subsection{Belluno: Cadore municipalities ${ }^{31}$}

Cadore is a historical, not administrative, region situated in the northern part of the province of Belluno, bordering Austria, the Region Trentino-Alto Adige/Südtirol and the Region Friuli-Venezia Giulia.

Once an under-developed and poor district, the Cadore territory has become home to a successful industrial cluster specialised in the production of eyewear, which flourished until the early 2000s and ensured high levels of well-being and employment.

Nevertheless, over the past 20 years, the Cadore territory has transformed from an extremely rich land to an abandoned and sparsely populated territory from which locals tend to flee.

This dramatic shift had a peak at the turn of 2000s when the district-based economy started to show the first symptoms of crisis following the delocalisation of eyeglasses production in other Italian territories. This resulted in crowding out most of the small producers, who were unable to cope with the new international prices at the wholesale level or to invest in

\footnotetext{
${ }^{31}$ Cadore territory covers overall 19 municipalities.
} 
their own brand or retail chain (Gambarotto and Solari, 2008). Tourism is another economic sector that has suffered in Cadore. Traditionally family-run, over the past two decades the local businesses engaged in the touristic domain have confirmed their low propensity to innovate and invest.

The mountain geomorphology of the Cadore territory gives rise to several key problems. These include limited street infrastructure, which does not to meet the mobility needs of local inhabitants, migrants and tourists; isolation; and disadvantages for the settlement of productive activities.

From a social perspective, there is a progressive population decline in Cadore with a severe contraction of the working age population and an elderly population increase with a growing demand for social services living in the area. Noteworthy are moreover a lower schooling level when compared to EU standards. Over a timeframe of 10 years (20072016), the number of residents in the Province of Belluno has dropped from 212,131 to 205,781 . The loss amounts to 6,350 residents $(-3 \%)$, out of whom half were lost over the last four years.

\begin{tabular}{|c|c|}
\hline Territorial challenges & Territorial resources \\
\hline $\begin{array}{l}\text { Progressive decline and } \\
\text { ageing of the local } \\
\text { population }\end{array}$ & $\begin{array}{l}\text { Arrival and prolonged stay } \\
\text { of asylum seekers since } \\
2011\end{array}$ \\
\hline $\begin{array}{l}\text { Drop in employment } \\
\text { following the } \\
\text { delocalisation of eyeglass } \\
\text { industrial districts }\end{array}$ & $\begin{array}{l}\text { Setting up of a social } \\
\text { cooperative specifically } \\
\text { designed to support work } \\
\text { integration of fragile } \\
\text { persons excluded by the } \\
\text { labour market }\end{array}$ \\
\hline Out-migration of youth & $\begin{array}{l}\text { Possibility to integrate } \\
\text { refugees to work in } \\
\text { domains lacking manpower }\end{array}$ \\
\hline $\begin{array}{l}\text { Supply of certain services } \\
\text { at risk, including a small } \\
\text { cinema and ski lift }\end{array}$ & $\begin{array}{l}\text { Cooperative commits the } \\
\text { needed resources to ensure } \\
\text { the delivery of both } \\
\text { services (although under } \\
\text { cost) }\end{array}$ \\
\hline $\begin{array}{l}\text { Strong } \\
\text { polarisation }\end{array}$ & $\begin{array}{l}\text { Engagement of different } \\
\text { stakeholders, including } \\
\text { local authorities, in the } \\
\text { governing bodies of the } \\
\text { social cooperative to } \\
\text { facilitate the management } \\
\text { of conflicts }\end{array}$ \\
\hline
\end{tabular}




\subsection{Welcoming asylum seekers: the model of the community cooperative Cadore scs $^{32}$}

Cadore cooperative emerged as a local community venture, particularly following the initiative of the Mayor of Valle di Cadore and of the Comunità Montana. Its birth, in 2008, was the outcome of a political endeavour, which gained the support of a critical mass of local inhabitants. They experimented a participatory modus operandi whereby the local population engages actively in both the production of key services and in the debate on relevant issues affecting the Cadore territory. The establishment of a community cooperative, owned by a large portion of local inhabitants representing different stakeholders (local authorities, workers, volunteers, fragile citizens) and sectors (nonprofit, public and conventional private sectors) induced this participatory approach. Ten municipalities are currently members of the Cadore cooperative ${ }^{33}$.

Two distinct phenomena influenced the choice to set up a cooperative. First, the decision to liquidate a local consumer cooperative set up at the end of the $19^{\text {th }}$ century, implying that all of its assets would be transferred to the national mutual cooperative fund in compliance with the asset lock regulation ruling all kind of coops in Italy. Second, the delocalisation of the eyeglasses industrial district upon the local territory resulted in dramatic consequences, such as the decrease of employment by $33 \%$.

The answer to the above-mentioned issues was to set up a new social cooperative ${ }^{34}$, specifically designed to pursue the interest of the entire community and support the work inclusion of unemployed people and people at risk of social exclusion and merge it with the older consumer cooperative to access its assets. Welcoming asylum seekers and supporting their social and work integration is only one of the diversified activities carried out by the Cadore cooperative. These include also environmental engineering to protect the environment against the risks of hydrogeological instability; community tourism; the management of a multi-purpose centre and refreshment bar (whose management has been contracted out by the local municipality) placed along the bicycle lane "Lunga via delle Dolomiti" and the supply of numerous services that would otherwise be at risk of survival. The Cadore cooperative operates over a rather large territory, including sixteen municipalities located in the Cadore territory and four additional municipalities of the province of Belluno.

The Cadore cooperative, which has been accredited by the Veneto region for its employment services, struggles to bring about and take stock of recipients' skills, equips

\footnotetext{
${ }^{32}$ Interview with Claudio Agnoli, emeritus president and founder of Cadore Social Cooperative.

33 The ten following municipalities are members of the Cadore social cooperativesocialcooperative: Valle di Cadore; San Vito di Cadore; Auronzo di Cadore; Lozzo di Cadore; Pieve di Cadore; Cortina d'Ampezzo; Calalzo di Cadore Santo Stefano di Cadore; Alleghe and Cibiana di Cadore.

${ }^{34} \mathrm{~B}$ type social cooperatives are set up to facilitate the work integration of disadvantaged people. $30 \%$ of the overall workforce employed by B type social cooperatives must be represented by disadvantaged workers, who can be integrated in various economic sectors. Many B type social cooperatives endeavour to empower their disadvantaged workers by encouraging their active engagement and not simply their work integration. Cadore social cooperative is in this respect a case in point, as it counts several disadvantaged people among its members.
} 
its beneficiaries with the tools required to search for employment, facilitates their social integration and develops individualised employment paths ${ }^{35}$.

The reception of asylum seekers has been carried out thanks to annual contractual agreements made with the Prefecture of Belluno since 2011 following competitive tenders aimed at outsourcing the management of CAS (Extraordinary reception centres) ${ }^{36}$.

From the very beginning, the Cadore cooperative has chosen to welcome a limited number of asylum seekers and to implement a decentralised housing model, which facilitated the inclusion of the newcomers in the local community and their path towards autonomy. Beyond its contractual obligations with the Prefecture, the Cadore cooperative is continuously experimenting with new services, which aim at favouring the social and work integration of recipients while contributing to regenerating the Cadore territory ${ }^{37}$.

\subsection{Impact upon the local community and recipients}

When compared to other mountain territories with similar characteristics, the answer to the asylum challenge of this territory has been less hostile, precisely because it was mediated by the Cadore cooperative. The Cadore cooperative faced this new challenge by adhering to its founding values and principles. These include the promotion of a fruitful dialogue with the various stakeholders, including local administrations and the local population, with a view to keep a balance between the various groups engaged.

The social inclusion mission of the Cadore cooperative had a role in pushing local inhabitants to face the challenge of welcoming asylum seekers collectively. Indeed, local inhabitants are well aware that the cooperative struggles to integrate many fragile citizens who would be otherwise at risk of social exclusion and ensure the survival of local services (both a local cinema and ski lift). Albeit not essential, the delivery of these services enables to strengthen trust relations and contributes to improving the quality of life of local inhabitants. Moreover, the promotion of initiatives aimed to nourish a welcome culture has contributed to changing the perception of the local population and has activated numerous spontaneous collaborations with local inhabitants. Many of these collaborations have turned into work relations and contracts. At the same time, the active engagement of volunteers has a role in building relational bridges that enhance of social cohesion. The strong local anchorage of the Cadore cooperative has also enabled to start up new collaborations with other social enterprises and with mainstream enterprises, including one working in the eyewear domain.

At the moment, out of the 31 asylum seekers and refugees hosted in Cadore, eight are regularly employed with diverse contractual agreements either by the Cadore cooperative in one of its various economic sectors or by other local enterprises. Noteworthy is that twelve former recipients have decided to settle down in Cadore territory and two Afghanis regularly employed have recently decided to escape to avoid being expelled. The Cadore cooperative has contributed to the accomplishment of two family reunifications.

\footnotetext{
${ }^{35}$ All beneficiaries are registered at the Pieve di Cadore Employment Centre and, if age requirements are fulfilled, they are also registered in the European Youth Guarantee Scheme.

${ }^{36}$ The Cadore cooperative is currently running four CAS located in Valle di Cadore, Pieve di Cadore, Lozzo di Cadore and Santo Stefano di Cadore.

${ }^{37}$ Interview with Luca Valmassoi, in charge of coordinating reception activities on behalf of the Social Cooperative Cadore.
} 
New economic initiatives recently launched by Cadore cooperative include the cultivation of a special type of artichoke - i.e. the mountain artichoke - by a mixed group of disabled people and asylum seekers.

The growth of turnover and strong commitment of employees corroborate the sustainability of both the development strategy undertaken by the Cadore territory and its welcome model developed through this community-based enterprise.

Key features of this community-based model include its ability to address new challenges and needs constantly arising at the local level and a strong inclination towards entrepreneurship. The combination of these features has enabled to experiment with innovative integration paths that have a role in regenerating the local territory and community.

While the Cadore cooperative can be considered as a key problem-solver of the local community, its development potential is still far from being fully harnessed, as highlighted by some of its members. Key problems hampering the ability of the cooperative to unfold its potential include the inability of some Cadore public administrators and representatives of the central government (i.e. Prefecture, municipalities, etc.) to understand the specificity of social enterprises, for instance by designing competitive tenders where the social dimension is adequately acknowledged. A case in point is the selection mechanisms designed to recruit the providers of welcome services. The most recent tenders do not reward the model of dispersed accommodation and fail to valorise the capacity to support recipients in their path towards autonomy. In line with the 2017 Minniti-Orlando Decree, these tenders favour big managing entities that are able to provide a wide range of standardised rather than individualised services. As such they indirectly penalise small organisations, like the Cadore cooperative, that succeeded in generating a beneficial impact upon the community by welcoming asylum seekers.

The strong opposition to newcomers and the general increased hostility, which is spreading across Italy and Europe, is also reflected in Cadore and poses additional challenges.

\section{Sweden}

\subsection{Demographic dynamics and migration flows}

Sweden is still in full urbanisation process: every year Stockholm grows by 40,000 inhabitants, while the countryside and, above all, the regions of the north and the west have been increasingly losing population over the last decades. Less than $20 \%$ of the national population, which covers more than $70 \%$ of the Swedish territory, lives in those areas (OECD, 2016).

Despite the negative interregional net migration and a negative net fertility rate, overall remote regions in Sweden have a positive international net migration rate (Glesbygdsverket, 2008; OECD, 2018). Given the fact that international migrants tend to be young, these figures indicate that immigration to the countryside might contribute to a more positive age structure in the countryside (Warnes, 1992).

Following the OECD classification (2011), in Sweden there is one predominantly urban region (Stockholm, 21\% of total population), two intermediate regions $(30 \%)$ and 18 predominantly rural regions (49\%). Even if almost three-quarters of the foreign-born population resided in urban areas (Aslund, 2005; Damm, 2009) starting from 2007 there was a growing trend towards settling in rural areas, where the share of family migrants is higher than that of refugees (Niedomysil, Oesth and Van Ham, 2010). 
Considering the labour market, the employment of international migrants is somewhat higher in rural areas and small-scale localities than in larger localities both for men and women. Moreover, the gap between foreign-born and native-born populations is smaller in the countryside than in larger localities. Lastly, entrepreneurship is higher in rural areas.

\subsection{Asylum seekers, refugees and status holders: Reception conditions and integration}

Sweden received 163.000 asylum seekers in 2015. That was the highest number of asylum seekers per capita ever registered in an OECD country. Three in four applicants were below 30 years of age, 70.000 were in school age (children) and there were 35.000 unaccompanied minors (OECD, 2016).

Year 2016 witnessed a very significant decrease in the number of people seeking for international protection. Overall, Sweden registered 29.000 new asylum applications, which is less than one fifth of the number registered in 2015, and the lowest annual figure recorded over the past seven years. However, given the extraordinary number of applicants registered in 2015, significant challenges persist today. The average processing time for asylum applications amounts to 328 days: over the last years, the Migration Agency tried to cope with a huge backlog of pending applications. In fact, the Migration Agency accomplished a record number of first-instance asylum decisions totalling to almost 112.000 with 60 percent of them being positive.

In Sweden, the reception of asylum-seekers has been so far managed through a decentralised approach, which strongly relies on the active role of local municipalities (the so called "whole-Sweden" approach). This system has its roots in the welcoming practices experimented in the nineties when many refugees from former Yugoslavia were hosted in Sweden. In addition, many areas where the mining sector is key have a longstanding experience of international immigration. Nevertheless, today a new government initiative is under discussion to improve a better distribution of asylum seekers across the national territory.

The local system of reception in Sweden provides two main options for the newcomers: if asylum-seekers have sufficient own financial resources, they can freely choose where to reside, pending recognition or not of their refugee status; often they choose urban areas, for more job opportunities and/or because they have relatives or friends there. If they do not have enough resources, the Swedish Migration Agency (Migrationsverket) places them to different regions ${ }^{38}$. Apartments are usually private and the State rents them from large companies, which own entire real estate complexes.

When refugees and status holders are granted a residence permit, either the Swedish Board of Migration offers them a residence in a given municipality, or they can find a place of residence on their own. With a view to support a widespread and balanced displacement of migrants across the national territory, rural areas are nowadays interested in the placement of asylum-seekers. There are no governmental intentions of repopulating them and, therefore, migrants are not intentionally sent to villages in demographic crisis. However, the local economic and service system and the previous presence of other migrants are considered in order to decide the allocation (OECD, 2016; OECD, 2018a).

\footnotetext{
38 The total number of asylum seekers registered in the reception system at the end of 2017 was
} 76.640, of which just over 35.000 were placed under the Migration Agency accommodation system. 
The preferred forms of accommodation for housing asylum seekers are individual flats, which are rented to most municipalities working with the Migration Agency in Sweden. However, rented apartments are usually very small and often not in good conditions, as the owners do not invest in their maintenance ${ }^{39}$.

\subsection{Economic and social integration}

As highlighted by several studies (e.g. in the Forced Migration Review), traditionally, people seeking for asylum in Sweden have a good level of education and, therefore, aim to rather qualified jobs. However, over the last years, the share of asylum seekers with low qualifications has increased. Out of the people aged 20-64 who applied for asylum over the period 2004-2014, 40\% held just a primary or lower-secondary education, almost twice the share observed in the previous decade (OECD, 2018a).

Asylum seekers are exempted from the requirement to have a work permit under the following conditions; that they have identity documents or other means to establish their identity, that Sweden is responsible for their asylum application, and that there are solid reasons for their application in Sweden. In 2017, Sweden granted to 14.946 asylum applicants the right to seek work.

Asylum seekers cannot generally work in areas that require certified skills such as in the health care sector, so their choice is limited to unskilled jobs. Jobs are not easy to get because of language requirements and the general labour market situation with high youth unemployment. Over the recent years, the government has launched a specific programme aimed to help foreign immigrants upgrade and gain new skills through the creation of fast tracks by the Swedish Public Employment Service in cooperation with industries. Should an asylum seeker obtain a job offer at another place in Sweden, he or she can move there and get nominal support for the living costs.

The current government introduced the possibility to switch from being asylum seeker to labour migrant. This is part of a governmental strategy aimed at developing labour migration of third-country nationals endowed with the skills needed by the labour market in Sweden. Therefore, those who obtain jobs are able to improve their economic situation and possibly to switch from being an asylum seeker to a labour market migrant, if they manage to work 4 months before receiving a final negative decision at the second instance.

Nevertheless, as the next case study - focused on the municipality of Avesta in Dalarna Region - shows, the integration of migrants in remote areas is very challenging.

\subsection{Dalarna: the Municipality of Avesta}

Dalarna $\left(31.151 \mathrm{~km}^{2}\right)$ is among the Swedish counties that cover the biggest variety in terms of physical geography: deciduous forests, various types of coniferous forests, foothill and

\footnotetext{
${ }^{39}$ The monthly amounts of financial allowances differ for applicants staying in accommodation centres where food is provided free of charge (and the allowance only covers pocket money), and applicants staying in other accommodation, where the allowance should also cover food. Asylumseekers in Sweden receive a daily pocket money of about 7 euros (a smaller amount is provided for each of their dependent children), with which to meet the expenses for food, clothes and all the extras, while they receive free accommodation and free essential services (school, hospital and doctor, etc.), offered by national and local institutions to those without sufficient own resources. Asylum seekers can apply for extra allowances for expenses that are necessary for a minimum living standard, such as cost of winter clothing, glasses, supplements, handicap equipment and infant equipment.
} 
alpine regions. Dalarna's total land area is 2,8 million hectares, of which 1,9 million hectares are productive forest land: this is roughly $8 \%$ of the total area of productive forest land in Sweden.

The region, about $250 \mathrm{~km}$ far from Stockholm - well-connected by train to the capital city and with the presence of two commercial airports - consists of 15 municipalities of which Falun, the main town and the seat of local government, has the biggest share of residents (55.000).

In 2017, the total population of Dalarna was 286.165. An increase in the average age has been marked over the recent years, despite the population rejuvenation in some bigger municipalities also due to the arrival of migrants.

Key economic sectors include human health and social work activities (in Falun there is the largest hospital in the region, with 3.650 employees, and many elderly people live in the area), education, wholesale and retail trade, industry (metallurgy) and still partly mining (copper). The forest sector, which is highly mechanised, and agriculture offer very few job opportunities. The total number of enterprises amounts to 13.000; among them, the most important is $\mathrm{ABB}$ (electric power engineering), in Ludvika town, with 2.600 employees ${ }^{40 .}$

A key actor in the asylum domain is the municipality of Avesta, which is located $70 \mathrm{~km}$ south of Falun and $160 \mathrm{~km}$ North-East of Stockholm, to which it is connected by a railway line. In the Avesta territory there are several medium and small villages, often in the middle of the countryside and forest. In the recent past, families settled in these villages because of employment opportunities in local mines. Therefore, blocks of flats are still present in many villages. There are locally a strong labour movement and Christian roots traditions.

With regard to demographic data, the municipality of Avesta had 28.744 inhabitants in 1968, when the local mining sector was still fully active. The population dropped drastically in the following decades to a minimum of 22.022 people in 2014. Since then, there has been a demographic upturn, in relation to the arrival of asylum seekers, which led to a population growth amounting to 23.256 in 2017.

\begin{tabular}{|l|l|}
\hline Territorial challenges & Territorial resources \\
\hline $\begin{array}{l}\text { Progressive decline and } \\
\text { ageing of the local } \\
\text { population }\end{array}$ & $\begin{array}{l}\text { Arrival and prolonged stay } \\
\text { of asylum seekers }\end{array}$ \\
\hline $\begin{array}{l}\text { No explicit strategy at } \\
\text { municipal level to favour } \\
\text { the permanence of migrants } \\
\text { once they have a residence } \\
\text { permit as refugees }\end{array}$ & $\begin{array}{l}\text { Labour shortages that could } \\
\text { in principle attract refugees } \\
\text { and status holders }\end{array}$ \\
\hline $\begin{array}{l}\text { Supply of basic goods and } \\
\text { services at risk (e.g. } \\
\text { schools) }\end{array}$ & $\begin{array}{l}\text { Survival of public services } \\
\text { depends upon the } \\
\text { permanence of recipients on } \\
\text { the territory }\end{array}$ \\
\hline
\end{tabular}

${ }^{40}$ Source of data: Region Dalarna development agency. 


\begin{tabular}{|l|l|}
\hline Tourism underdeveloped & Availability of territorial \\
resources & and \\
environmental and & landscape heritages that \\
& could be better valorised by \\
engaging local actors (i.e. & Agency Dalarna) and \\
& refugees \\
\hline
\end{tabular}

\subsection{Welcoming asylum seekers: the key role of the municipality}

In Dalarna region, the presence of asylum seekers is significant. Over the last few years, massive arrivals of migrants from non-EU countries led to the creation of big reception centres. Today, on the contrary, migrants are allocated in small apartments, usually inside residential buildings that were built in the $50 \mathrm{~s}$ and $60 \mathrm{~s}$ in the outskirts of rural municipalities, primarily for the housing needs of miners and their families.

Once they get the recognition of their status (the process lasts on average 2-3 years, even up to 5 or more), many asylum-seekers- particularly youth and singles- hosted in the region, decide to move to urbanised areas. Families are less inclined to leave villages in which their kids still attend school. Overall, however, refugees and status holders are not inclined to settle in the territory. Therefore, the problems of depopulation and of ageing societies remain unsolved. Key obstacles preventing their settlement include limited access to housing due to the high renting prices on the private market and the bad conditions of most public stock of buildings. An additional obstacle is the lack of job opportunities, which is worsened by language learning difficulties faced by most recipients.

An important player with regard to the integration of asylum-seekers, refugees and status holders is the Local Development Agency, Region Dalarna Agency, comprising Dalarna's 15 municipalities and the County Council, which is responsible for promoting and coordinating regional development in the country. Migration and asylum issues are among the tasks of this agency as well acting against rural depopulation.

From the perspective of the multi-level governance for local integration (OECD, 2018a), the reception strategy in Dalarna region results from the intersection of four main actors: the Swedish Migration Agency (central government level), the Region Dalarna (regional level), the 15 municipalities (local level) and civil society, that is associations, informal groups, churches, clubs, etc. (community level).

Region Dalarna Agency interacts with the various actors engaged in supporting migrants' social and work integration: it seeks to build bridges between employers and asylum seekers, involving them in a wider development strategy.

Worth noticing is the municipality of Avesta, where asylum seekers find accommodation in apartments that rented on the private market by the national immigration agency: migrants are normally placed in the blocks of flats once occupied by the families of miners. The apartments are usually located in small rural villages or suburbs. There is, nevertheless, a trend to concentrate migrants in some specific areas and buildings and, as a result, to induce them to live separately from the local inhabitants. This entails risks of segregation in the school system mainly because there are very few opportunities for mutual interaction (OECD, 2018a). 
In Avesta an important actor, fostering the social inclusion of asylum-seekers, is the local branch of the international association Save the Children, present nationally in Sweden under the name of Radda Barnen. The group of local volunteers is composed essentially of women, most of whom are retired. The local Save the Children section has been active for many years and, about 4 years ago (in relation to the massive arrival of asylum seekers), has opened a playing and meeting space addressed especially to foreign mothers and their children, aged between 0 and 5 years. The centre is located in the rural village of Horndal, which is $25 \mathrm{~km}$ away from the main town of Avesta and connected by a toll-free bus. About 200 asylum seekers now live in this rural suburb, built in a recent past for hosting mining workers and their families. The local municipality pays the rent of the centre, which is located in one of the buildings inhabited by asylum seekers, and IKEA supports the activities financially.

\subsection{Impact upon the local community and recipients}

Over the recent years, the presence of asylum seekers has allowed for the survival of some basic services, such as small grocery stores and schools, otherwise at risk of closure or strong downsizing, due to the progressive ageing of the population and demographic decline.

Nevertheless, even if this is a territory hit by demographic decline, there is no explicit strategy at municipal level to favour the permanence of migrants on the spot once they have a residence permit as refugees, which is considered as a key objective in the OECD checklist regarding refugees multi-level governance. The municipality focuses its efforts primarily on language courses, in the belief that only those who know Swedish well will have the chance to work, be integrated and hence settle down in the territory. However, language teaching follows a very formalised and traditional approach, which fails to consider both the needs of the labour market and migrants, who are willing to enter it.

With regard to the Save the Children centre, occasionally, also some Swedish mothers benefit from it but users are mainly foreign mothers with young children coming from Syria and Afghanistan. Their husbands, during the day, go to Avesta, to meet their friends, to take language courses or just to spend some time at the bar. Foreign families, often numerous, live in very small apartments: there is no space for children to play, especially during the winter when it is very cold outside. Similarly, women lack meeting places and normally do not have the opportunity to go to the centre of Avesta, having to take care of their children.

The centre managed by Save the Children was created to meet these needs. The centre offers the possibility for children and their mothers to be involved in recreational activities, within the playground space, but also outside where they learn how to skate on ice. Mothers also learn how to dress their children in the winter and to deal with the low temperatures of Sweden correctly.

Much of the association's work deliberately aims at transmitting to asylum seekers (first of all to mothers) Swedish values and way of life, for educational purposes, in the name, for example, of home security, children's health, civil cohabitation, etc.

\section{Conclusions}

Analysing the migration phenomenon in remote areas implies that attention is paid specifically to asylum seekers, refugees and status holders as numerically more relevant nowadays in these areas due to EU member states' dispersal policies. 
The comparative case study analysis shows one common positive outcome of reception initiatives of asylum seekers, refugees and status holders in remote areas with a declining population, irrespective of the management of the reception process as such. That is the short-term contribution to the local economy. Indeed, reception initiatives generate locally a new demand for services, housing, basic commodities (e.g. food, clothes) and create new employment opportunities for the local population. These changing conditions have a clear beneficial impact upon local enterprises, tenants of houses, retailers of basic services and the communities at large, which also benefit from the supply of services otherwise at risk of being withdrawn (i.e. schools, healthcare). The latter is one of the main reasons pushing territories with depressed economies (e.g. Weitensfeld in Austria and Cadore in Italy) to host asylum seekers. However, the new demand for goods and services is per se artificial and doomed to run out if and when recipients move (or are transferred) elsewhere.

Only strategies aimed at both triggering the long-term socio-economic revitalisation of hosting communities and taking stock of the skills (formal and informal) of recipients can enable to go beyond the "economy of asylum seekers' reception" and activate new development dynamics that are expected to last over time and generate social and territorial innovation, as the Cadore case clearly shows.

The comparative case study analysis corroborates that remote areas can turn into highly adequate contexts to socio-economic inclusion for asylum seekers, refugees and status holders when a number of enabling conditions unfold. These include:

- Integration of asylum seekers, status holders and refugees as a component of local development strategies in remote areas. This implies the re-adjustment of policies not necessarily designed for asylum seekers - like rural development policies - for asylum purposes (e.g. Hofeim Land in Germany) as well as the incorporation of integration goals into welfare, health, educational, and housing policies.

- Existence of a critical mass of people with similar values and sensitive to asylum seekers' integration. Ideally, this may imply the active engagement of renowned persons that are well respected by local inhabitants such as the mayor, the city council, the priest, the church community, the local authorities, as well as the local entrepreneurs, artisans, local businesses, representative of third sector organisations (e.g. Hofeim Land in Germany).

- Activation of bottom-up local development and social inclusion processes by local actors, including groups of volunteers, third sector organisations and social enterprises (e.g. Hofheim Land in Germany and Cooperativa Cadore in Italy).

While in all countries analysed there is an apparent slow policy shift from a system of assistance towards one of work integration, matching the supply of labour with demand continues to be challenging even in territories with labour shortages in given sectors (e.g. Avasta in Sweden). This confirms the need to develop more effective mechanisms and schemes whereby the demand of labour by local firms can be assessed and the matching with the new supply of labour (i.e. asylum seekers and, even more so, refugees and status holders) can be facilitated through proper training paths. The latter should be designed to support the early access of recipients to the labour market. Against this backdrop, the case studies highlight the importance of designing individualised integration paths backed by social inclusion initiatives that are more likely to pave the way for spontaneous collaborations and work relations with local inhabitants.

All case studies show that when they succeed in finding stable jobs and accommodations, remote and mountain localities become attractive localities for refugees and status holders 
usually more inclined to move to urban centres. Strategies for supporting the integration of asylum seekers, refugees and status holders in the long-run need a territorial approach (OECD, 2018a) that includes the following specificities in remote areas with declining population:

- Preparation and engagement of local inhabitants at an early stage and in a sustainable way. Local inhabitants in remote areas can be involved directly through various modalities in key decision-making processes, due to the small numbers, and thus directly experience the opportunities and benefits as well as share the risks and problems connected with the welcoming of asylum seekers and the cohabitation with refugees and status holders.

- Adoption of a full-scale system of decentralised housing for asylum seekers, accommodated in small groups rather than in big centres.

- Design of innovative tools whereby the practice-oriented skills of migrants, especially asylum seekers, refugees and status holders, are brought about, mapped and valorised with a view to revitalise the environmental and cultural heritage of the hosting territory. The proper utilisation of practice-oriented skills can contribute to valorising traditional arts, works and practices that may be at risk of extinction. In remote areas, this may include the revival of traditional construction techniques (e.g. how to restore dry stonewalls), sheep-farming and the cultivation of antique crops that can conversely have a role in promoting sustainable tourism and breaking the risks of hydrogeological instability thanks to the regeneration of abandoned lands prompted.

- Activation of socio-economic integration pathways in local communities right after the arrival of asylum seekers on the territory. This presupposes that the protection status determination is as brief as possible and integration pathways are already underway before the recognition of the status determination. In remote areas a long wait without having the possibility to interact with the hosting community can have a stronger role in exacerbating social exclusion when compared to urban settings, where ethnic communities and networks are normally widespread and contribute to buffering the negative consequences of mis- and poor management of reception and integration initiatives.

- Design of educational policies supporting the social inclusion of foreign-born children; housing policies preventing ghettoisation of refugees and status holders who decide to settle down; and territorial welfare services accessible to all recipients. Segregation and ghettoisation are indeed likely to exacerbate social polarisation much more in remote areas than in urban contexts where the population tends to be more heterogeneous.

- Development of fruitful relations by different levels of governance and by local actors and third sector organisations in charge of managing reception and/or integration services. The development of collaborative rather than competitive relations among public and private actors (mainly third sector organisations and social enterprises) seems to be more likely to pave the way for the experimentation of innovative welcome paths that can align the objective of securing rural employment to recipients with that of contrasting depopulation in remote areas.

Consistently with the case studies analysed by OECD in its 2018 report, the Cadore case sheds light on the need to adapt contracts and public procurement to third sector 
organisations, while safeguarding transparency as a key dimension (OECD, 2018a). Collaborative relations seem to be in this respect better suited to enhance cooperation among public entities and third sector organisations sharing similar general interest goals. Collaborative relations can indeed allow for the definition of effective policy strategies that are suited to address diverse needs arising in remote communities at a time, such as supporting the survival of local public services and facilitating the integration of status holders and refugees in the local labour market.

This requires redefining the mechanisms whereby reception services are outsourced to private providers and the progressive replacement of competitive tenders with collaborative modalities of interaction between public authorities and third sector organisations. While competitive tenders are the most suitable mechanism for contracting out emergency reception services with precise quantitative and qualitative features, the design of innovative services incorporating a relational dimension - like the work integration of asylum seekers and refugees - calls for the development of collaborative partnerships.

The advantages of a collaborative approach are numerous: the engagement of third sector organisations as co-producers, including social enterprises open to the participation of a plurality of stakeholders, contributes to attracting additional resources on a stable basis, including voluntary work and donations that would not had been otherwise allocated to welfare issues. Furthermore, it has a role in enhancing the social capital that is embedded in local communities. The active engagement of social enterprises that have a strong entrepreneurial orientation is then key in both integrating recipients and triggering territorial and social innovations.

On the contrary, when civil society is relegated to play a minor role, the design of innovative integration trajectories appears to be more challenging. The same occurs when the welcome process relies only on the work and/or goodwill of a few persons rather than being embedded in the community through the engagement of key actors. As the Swedish and Austrian case studies demonstrate, in those instances which recipients rarely decide to settle down in remote areas and normally prefer to move to urban contexts whenever they have the possibility.

As shown by the Hofheim case study the wish of migrants to stay can be encouraged through proper policy strategies. In line with OECD findings, inter-municipal coordination, coordination across different levels of government, connection of integration purposes with local development and active involvement of third sector organisations have the potential to generate a win-win solution, both in terms of integration of recipients and revitalisation of the local economy (OECD, 2018a). 


\section{Interviewees}

Visit to Austria - Carinthia (April 2018)

1. Elisabeth Steiner, owner of the Gasthof Bärenwirt

2. Franz Sabitzer, mayor of Weitensfeld im Gurktal

3. Head of the middle school of Weitensfeld im Gurktal

4. 7 asylum seekers hosted at the Gasthof Bärenwirt (focus group and 2 additional single interviews)

5. Marika Gruber, researcher at Fachhochschule Kärnten

Meeting with key persons experts in migration issues in Germany - North Bavaria (May 2018)

6. Stefan Kordel researcher at Institute fuer Geographie, University of Erlangen.

7. Norbert Kreuzkamp, expert in migration and asylum policies (ACLI)

Visit to Italy - Cadore (February 2018)

8. Claudio Agnoli - Social Cooperative Cadore, President Emeritus

9. Luca Valmassoi - In charge of reception for the Social Cooperative Cadore

10. Monica Argenta - anthropologist of the Social Cooperative Cadore

11. Matteo Toscani -former mayor of the Municipality Valle di Cadore

\section{Vist to Sweden - Dalarna (24-28 of April 2018)}

12. Malin Gawell- Soderthorn University of Stockholm, Associated Professor, Deputy Head of School of Social Sciences

13. Susanne Stenbacka - University of Uppsala, Associate professor in Social and Economic Geography

14. Pablo Vilches - Region Dalarna agency (Falun), Integration Strategy Leader

15. Rikard Engblom - University of Uppsala, Doctoral Student in European Ethnology

16. Christer Gustavsson - Municipality of Ludvika (Dalarna Region), Integration manager

17. Kerstin Sahlqvist, Head of - Save the Children Association, Avesta (Dalarna Region) 


\section{References}

Andersson, R., A. Brama and E. Holmqvist (2010), "Counteracting segregation: Swedish policies and experiences", Housing Studies 25, pp. 237-256.

Aslund, O. (2005), "Now and forever? Initial and subsequent location choices of immigrants", Regional Science and Urban Economics 35, pp. 141-165.

Bender, O. and S. Kanitscheider (2012), "New Immigrants into the European Alps: Emerging Research Issues", Mountain Research and Development 32(2), pp. 235-241.

BLE (2017), Aktuelle Bekanntmachung: "500 Landinitiative".

Brezzi, M., Dijkstra, L., and V. Ruiz (2011), "OECD extended regional typology: The economic performance of remote rural regions", OECD Regional Development Working Papers, 2011/06, OECD Publishing, http://dx.doi.org/10.1787/5kg6z83tw7f4-en

Carrera, S. (2008), Benchmarking integraion in the EU. Analyzing the debate on integration indicators and moving it forward, Bertelsmann Foundation, Gütersloh.

Corrado, F. (2010), Ri-abitare le Alpi. Nuovi abitanti e politiche di sviluppo, Eidon.

Corrado, F., G. Dematteis and A. Di Gioia (2014), Nuovi montanari. Abitare le Alpi nel XXI secolo, Franco Angeli.

Damm, A. (2009), "Determinants of recent immigrants' location choices: quasi-experimental evidence", Journal of Population Economics 22, pp. 145-174.

Dematteis, G., A. Di Gioia and E. Durbiano (2017), L'interscambio montagna città: il caso della Città Metropolitana di Torino, Franco Angeli.

European Commission (2003), "Communication from the Commission to the the Council, European Parliament, the European Economic and Social Committee and and the Committee of the Regions on immigration, integration and employment", COM (2003) 336 final.

European Foundation for the Improvement of Living and Working Conditions (2007), Housing and integration of migrants in Europe, https://www.eurofound.europa.eu/publications/report/2007/quality-of-life-social$\% 20 \mathrm{Damm} \% 20$ policies/housing-and-integration-of-migrants-in-europe.

Eurostat (2018b), Asylum applicants in the EU, 2017, http://ec.europa.eu/eurostat/news/themes-in-the-spotlight/asylum201.

Fachhochschule Kaernten (2017), Pro-Migra - Prozessbegleitung: ...(ge)kommen, um zu bleiben... - Zuwanderung als Potenzial fur die Region Hermagor, http://www.iara.ac.at/2016/11/09/prozessbegleitung-gekommen-um-zu-bleibenzuwanderung-als-potenzial-fuer-die-region-hermagor/. 
Gambarotto, F. and S. Solari (2008), "Restructuring of local productionsystems: Two Italian case studies about responses to globalisation", Revue d'Economie Régionale e Urbaine 1, pp. 3-20.

Glesbygdsverket (2008), Sveriges gles-och landsbygder 2008.

Hagspiel, D. (2016), Culture of Welcoming in Upper Austria. A contribution for economic stability.

Helberg, C. (2010), "Every soul is needed! Process of immigration and demographic consequences for Swedish rural areas", Stockholm Research Reports in Demography.

Heleniak, T. (2018), From migrants to workers: international migration trends in the Nordic countries.

Iorio, M. and A. Corsale (2010), "Rural tourism and livelihood strategies in Romania", Journal of Rural Studies 26, pp. 152-162.

Kuepper, P. (2016), Abgrenzung und Typisierung laendlicher Raume, http://dx.doi.org/10.3220/WP1481532921000.

Lemaitre, G. (2007), The integration of immigrants into the labour market: the case of Sweden, OECD Publishing.

Lemaitre, G. and J. Dumont (2005), Counting Immigrants and Expatriates in OECD Countries, OECD Publishing.

Machold, I. and T. Dax (2015), Schluesselfaktor Zuwanderung, Migration in laendlichen Regionen Oesterreichs, Garstenauer Unterwurzacher.

Machold, I., T. Dax and W. Strahl (2013), Potenziale entfalten. Migration und Integration in landlichen Regionen Oesterreichs, Bundesanstalt fur Bergauernfragen.

Mathieu, J. (2015), "Überdurchschnittliches Wachstum? Zur Bevölkerungsentwicklung des Alpenraums seit 1950”, Schweizerische Zeitung für Geschichte, Vol. 2/65, pp. 151-163.

Maurer, O. and H. Wytrzens (2012), Demographic challenges in the Alpine Space - The Search for Transnational Answers, Freie Universitaet Bozen.

Membretti, A. (2016), "Immigrazione straniera e turismo nelle Alpi: l'accoglienza dei rifugiati come occasione per il rilancio delle terre alte", Informazione Sostenibile, http://www.informazionesostenibile.info/.

Mihailescu, V. (2011), "From Cow to Cradle. Mutations and Meanings of Rural Household in Postsocialism", International Review of Social Research.

Niedomysil, T., J. Oesth and M. Van Ham (2010), "The Globalisation of Swedish Marriage Fields", Journal of Ethnic and Migration Studies. 
Nordregio (2004), Mountain areas in Europe: analysis of mountain areas in EU member states, acceding and other European countries.

OECD (2016), International Migration Outlook 2016, OECD Publishing.

OECD (2018a), Working together for local integration of migrants and refugees, OECD Publishing.

OECD (2018b), International Migration Outlook 2018, OECD Publishing.

OECD/EU (2015), Indicators of Immigrant Integration 2015: Settling in, OECD Publishing, http://dx.doi.org/10.1787/9789264234024-en.

Perlik, M. (2011), "Alpine Gentrification: the Mountain Village as a Metropolitan Neighbourood", Journal of Alpine Research 99-1.

Piccinni, A. and P. Proietti (forthcoming), Multilevel governance of humanitarian migrants reception and integration approach for asylum seekers and refugees: from reception mechanisms to local integration policies, OECD Publishing.

Rhein, N. (2017), “Integration im Laendlichem Land”, Informationen zur Raumentwicklung, Vol. 2.

Scholten, P. et al. (2017), Policy Innovation in Refugee Integration? A comparative analysis of innovative strategies toward refugee integration in Europe.

Uhlich, E. and D. Moering (2016), "Vom Willkommengruss zur Integrationsarbeit im Hofheimer Land", Argumente und Materialien zum Zeitgeschehen 106.

UNSD (2017), "International migration statistics", United Nations Statistics Division, https://unstats.un.org/unsd/demographic/sconcerns/migration/migrmethods.htm\#B.

Viazzo, P. (2012), Demographic Change in the Alpine Space: Key Challenges for the Future, Oswin.

Warnes, T. (1992), Migration and the life course, Belhaven Press.

Weidinger, T. (2018), Residential Mobility of Refugees in Rural Areas of Southeastern Germany: Structural Contexts as Influencing Factors, Cambridge Scholars Publishings.

Wihtol de Wenden, C., Bourgoint, J. E. and E. Salvioni (2008), “Mesurer l'intégration: Le cas de la France, index territorial d'insertion socio-économique des nationaux de pays tiers", Sciences Po CERI.

Woods, M. (2016), International Migration, Agency and Regional Development in Rural Europe, http://dx.doi.org/10.5565/rev/dag.372.

Zanini, R. (2016), L'arco alpino tra spopolamento e neo-popolamento. 